\title{
Properties of Polymer Electrolyte Membranes Prepared by Blending Sulfonated Polystyrene with Lignosulfonate
}

\author{
Siang Tandi Gonggo ${ }^{1 *}$, Cynthia L. Radiman ${ }^{2}$, Bunbun Bundjali $^{2} \&$ \\ I Made Arcana ${ }^{2 *}$ \\ ${ }^{1}$ Physical Chemistry Research Groups, Faculty of Teacher Training and Educational \\ Sciences, Tadulako University, Kampus Bumi Tadulako, Tondo, Jl. Sukarno Hatta Km \\ 9 Tondo, Palu 94117, Indonesia, \\ E-mail: standigonggo@yahoo.com \\ ${ }^{2}$ Inorganic and Physical Chemistry Research Groups, Faculty of Mathematics and \\ Natural Sciences, Institut Teknologi Bandung (ITB), Jalan Ganesha No. 10, Bandung \\ 40132, Indonesia \\ E-mail: arcana@chem.itb.ac.id
}

\begin{abstract}
A polymer electrolyte membrane widely used in PEMFCs and DMFCs is a perfluorosulfonated membrane (the Nafion membrane). This perfluorosulfonated membrane material exhibits good chemical stability and proton conductivity, but it is very expensive and difficult to recycle. There is a high methanol crossover in DMFCs that causes a decrease in efficiency and performance of the fuel cell, so that a polymer electrolyte membrane with a low methanol crossover is needed as a substitute for the Nafion membrane. One of the materials that can be used as a polymer electrolyte membrane is the polyblends from sulfonated polystyrene-lignosulfonate (SPS-LS). Such polyblends were prepared by casting a polymer solution and characterized as polyelectrolyte membrane for DMFCs. The SPS was prepared by sulfonation of polystyrene with acetyl sulfate as the sulfonating agent. The membranes of the SPS-LS were characterized by analysis of functional groups, mechanical properties and methanol permeability. The maximum mechanical properties of the SPS-LS membrane were observed at an LS ratio of 7.5\%. However, the methanol permeability of the membrane increased with the increase of the LS ratio in the SPS-LS membranes. The properties of the membranes, especially their mechanical properties and methanol permeability, were close to that of Nafion ${ }^{\circledR} 117$ membrane, so SPS-LS membranes have high potential for use as polymer electrolyte membrane for direct methanol fuel cells.
\end{abstract}

Keywords: DMFC; lignosulfonate; polymer electrolyte membrane; polystyrene; sulfonated.

\section{$1 \quad$ Introduction}

The need for energy increases with the growing population and improving living conditions of mankind, especially in transport, industry and households. The main source of energy is fossil fuels, which are non-renewable. Exploration

Received October $20^{\text {th }}, 2010,1^{\text {st }}$ Revision February $20^{\text {th }}, 2012,2^{\text {nd }}$ Revision May $26^{\text {th }}, 2012,3^{\text {rd }}$ Revision July $11^{\text {th }}, 2012$, Accepted for publication October $11^{\text {th }}, 2012$.

Copyright (C) 2012 Published by LPPM ITB, ISSN: 1978-3043, DOI: 10.5614/itbj.sci.2012.44.3.8 
of fossil fuels continuously causes the fossil-fuel reserves to diminish. The fossil fuel crisis has begun to be felt in society. According to S.M. Javaid Zaidi and Takeshi Matsuura [1], fossil-fuel production will peak in 2020 and thereafter decrease. In addition, continuous use of fossil fuels can cause serious environmental problems, such as global warming, climate change, melting of ice caps, acid rain, pollution, ozone layer depletion, forest and agricultural land damage, etc. [2]. Therefore, we need alternative energy sources that are environmentally friendly and renewable. One such environmentally and renewable energy source is the fuel cell.

One type of fuel cell with potential as an energy source is the direct methanol fuel cell (DMFC), which uses methanol directly as a fuel. The DMFC, like any other fuel cell, consists of an anode, a cathode and an electrolyte. The electrolyte of the DMFC is a solid polymer membrane. The DMFC is very interesting because it operates at low temperatures and because of its potential use in automotive, stationary, portable power applications, etc [3].The most important part of a DMFC is the polymer membrane as the electrolyte, which is sandwiched between the electrodes (anode and cathode) to form the membrane electrode assembly (MEA), because the performance of the fuel cell is largely determined by the ability of the membrane to transfer protons. The ideal electrolyte membrane for a DMFC has high proton conductivity, no conducting electrons, good mechanical strength, thermal stability and chemical stability, no methanol permeability, highwater uptake above $100^{\circ} \mathrm{C}$, and low production costs $[1,4-6]$.

An electrolyte membrane commonly used for DMFCs is Nafion, due to its high proton conductivity, good thermal stability, chemical stability and mechanical strength [7-13]. However, this membrane is still quite expensive [7,13], and its conductivity decreases at higher temperatures and it shows high methanol permeability, which limits its application in DMFCs due to the consequent lowering of its efficiency. Therefore, polymer electrolyte membranes are needed that have properties as mentioned above. To get the ideal membrane is very difficult; if one of the criteria is met, a problem appears with another. This has caused the development of electrolyte membrane materials for DMFC's to become the center of attention of researchers. In this paper, one of the new materials for DMFC membranes is presented, which is synthesized by blending sulfonated polystyrene (SPS) with lignosulfonate (LS) at various ratios. LS consists of sulfonate groups and also contains carboxylic groups (-COOH) [14], which may facilitate proton conductivity in the membrane. Polymer electrolyte membranes were prepared by blending sulfonated polystyrene (SPS) with lignosulfonate (LS) in various ratios by casting a polymer solution. Properties of the membranes, such as the mechanical properties and methanol permeability, were measured. 


\section{$2 \quad$ Materials and Methods}

\subsection{Materials}

The materials used in this research,i.e. polystyrene (PS) $\left(\overline{M_{n}}=140.000 \mathrm{~g} / \mathrm{mol}\right)$ and lignosulfonate acid $\left(\overline{M_{n}}=7.000 \mathrm{~g} / \mathrm{mol}\right)$, were obtained commercially from Aldrich. Sulfuric acid (95-97\%), acetic anhydride (Synth, p.a.), dichloromethane (DCM), 2-propanol, NaOH (Vetec), methanol, N,N-dimethyl formamide (DMF), toluene, and n-butanol were commercially obtained from Merck.

\subsection{Methods}

The sulfonation of the polystyrene (PS) was prepared by the following procedure [15,16]. First, acetyl sulfate was freshly prepared for use as the sulfonating reagent: $12 \mathrm{ml}$ acetic anhydride was added to $24 \mathrm{ml}$ dichloromethane (DCM) in a three-neck tube under a nitrogen atmosphere. The volume of the DCM was twice that of the acetic anhydride. The solution was cooled at about $0^{\circ} \mathrm{C}$, then $6 \mathrm{ml}$ sulfuric acid (95-97\%) in stoichiometric amount to the desired degree of sulfonation in the polymer was added into solution under a nitrogen atmosphere. The molar amount of acetic anhydride was added in slight excess to the sulfuric acid, so that the latter was completely converted to acetyl sulfate. Finally, the three-neck tube was capped, and the acetyl sulfate resulted in DCM solution was ready to be used. The equipment that was used in this synthesis is illustrated in Figure1.

$21 \mathrm{~g}$ of atactic polystyrene (PS) was dissolved in $210 \mathrm{~mL}$ of DCM, which had previously been purged with nitrogen in a flask. The solution was maintained under nitrogen and then heated to $40^{\circ} \mathrm{C}$. The total amount of the prepared acetyl sulfate solution was added into the flask, and sulfonation was carried out for 80 minutes understirring. The reaction was stopped by adding $10 \mathrm{~mL}$ of 2-propanol and the resulting solution was cooled at room temperature. The sulfonated polymer was then precipitated in $1 \mathrm{~L}$ of distilled water at a temperature of about $80^{\circ} \mathrm{C}$. The polymer was filtered, washed for $2 \mathrm{~h}$ with distilled water at room temperature, and then filtered again. Finally, the sulfonated polymer was dried under vacuum at $60^{\circ} \mathrm{C}$ for two days.

\subsection{Preparation of Membranes}

A solution $(1.5 \mathrm{~g} / 20 \mathrm{~mL})$ of the sulfonated polystyrene (SPS) in a toluene/nbutanol mixture $(7 / 3 \mathrm{v} / \mathrm{v})[15,16]$ was poured into a petri dish and placed in a vacuum oven at room temperature until the solvent had completely evaporated. Then, the temperature was risen to $50^{\circ} \mathrm{C}$ and the membrane was vacuum-dried further for one hour. Finally, the membrane was recovered as a sheet membrane 
from the petri dish and soaked in distilled water for $3 \mathrm{~h}$, before being tested. The membrane thickness was measured in the hydrated state by micrometer. For preparing the sulfonated polystyrene-lignosulfonate, the SPS was dissolved into a mixture of toluene/n-butanol $(7 / 3 \mathrm{v} / \mathrm{v})$, and the LS was dissolved in N,Ndimethyl formamide (DMF) with various concentrations. Both solutions were a mixture of toluene/n-butanol to DMF of 4/1 (v/v), and the solutions were stirred until homogeneous. The solutions were then cast onto a petri dish like the SPS membranes mentioned above, and finally the membranes were kept in distilled water.

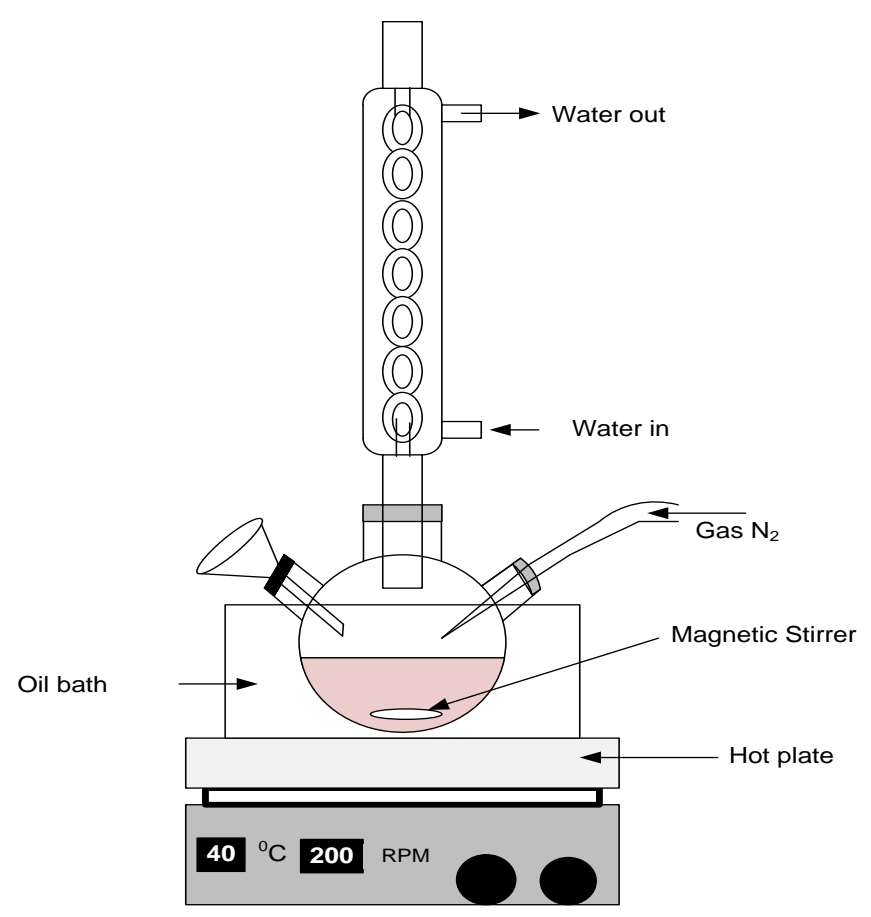

Figure 1 Equipment used for the synthesis of SPS.

\subsection{Analysis of Functional Groups}

The FTIR spectra of the SPS-LS membranes were characterized using a FTIR spectrometer (Shimadzu IR PRESTIGE-21). The samples were prepared using $\mathrm{KBr}$ pellets. The FTIR spectra of the SPS-LS powders were taken at wave numbers in the range of 400 to $4500 \mathrm{~cm}^{-1}$. 


\subsection{Analysis of Mechanical Properties}

The mechanical strength of the membranes was measured by an Instron testing machine (Japan) with an operating head load of $50 \mathrm{~N}$. The cross-sectional area of the samples was calculated. The membranes were then placed between the grips of the testing machine. The grip length was $4 \mathrm{~cm}$, and the speed of testing was set at a rate of $50 \mathrm{~mm} / \mathrm{min}$ [17]. The Young modulus was calculated according to Eq. (1) [16].

$$
\text { Young Modulus }=\frac{\text { Tensile Strenght }}{\text { Strain }}
$$

\subsection{Analysis of Methanol Permeability}

Methanol permeability measurement was carried out using a diffusion cell. Initially, one compartment of the cell, $B\left(\mathrm{~V}_{\mathrm{B}}=100 \mathrm{~mL}\right)$, was filled with only deionized water. The other compartment, $\mathrm{A}\left(\mathrm{V}_{\mathrm{A}}=100 \mathrm{~mL}\right)$, was filled with $5 \mathrm{M}$ methanol solution in deionized water. The membrane with a diffusion area of $1.77 \mathrm{~cm}^{2}$ was sandwiched by O-ring shaped Teflon and was clamped tightly between the two compartments, as illustrated in Figure 2.

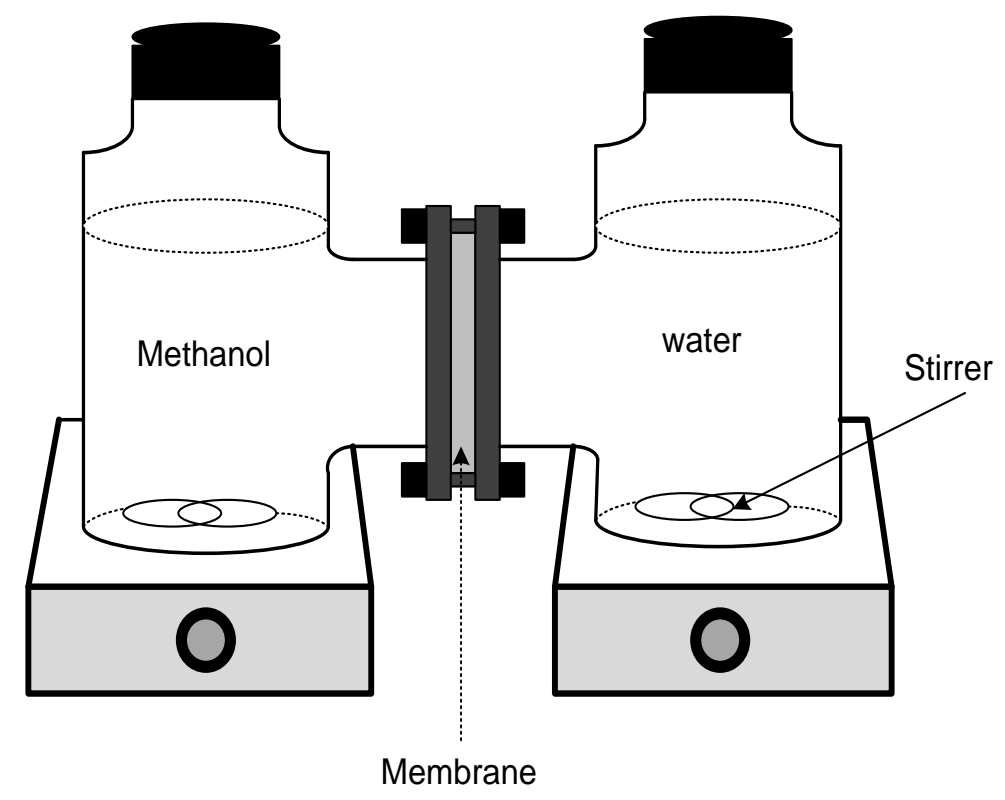

Figure 2 Illustration of the diffusion cell.

This diffusion cell was kept stirring slowly during the experiment. The concentration of methanol diffusing from compartment A to compartment B 
across the membrane was detected every time using Gas Chromatography (GC). The methanol concentration in compartment B was calculated according to Eq. (2):

$$
C_{B}(t)=\frac{A}{V_{B}} \times \frac{D K}{L} \times C_{A}\left(t-t_{0}\right)
$$

Where $C_{B}$ and $C_{A}$ are the methanol concentrations in the permeated compartment and the feed compartment, respectively. $\mathrm{A}, \mathrm{L}$ and $\mathrm{V}_{\mathrm{B}}$ are the effective area of the membrane, the thickness, and the volume of the permeated compartment, respectively. $\mathrm{D}, \mathrm{K}$, and $\left(\mathrm{t}-\mathrm{t}_{0}\right)$ are the methanol diffusion, the partition coefficient between the membrane and the adjacent solution, and the time interval, respectively. The methanol permeability is defined as the product of diffusion and solubility (DK), and the concentration change of $C_{B}$ with time is obtained from a linear slope, using Eq. (3).

$$
\begin{aligned}
& \text { Linear slope }=\left(\frac{d C_{B}(t)}{d t}\right)=\frac{A}{V_{B}} \times \frac{D K}{L} \times C_{A} \\
& \text { Methanol permeability }=D K=\left(\frac{d C_{B}(t)}{d t}\right) \times \frac{V_{B} \cdot L}{A \cdot C_{A}}=\frac{C_{B}(t) \cdot V_{B} \cdot L}{A \cdot C_{A}\left(t-t_{0}\right)}
\end{aligned}
$$

\section{Results and Discussion}

The preparation of the SPS-LS membranes with various concentrations of LS $(2.5,5,7.5,10$, and $12.5 \%(\mathrm{w} / \mathrm{w}))$ having been performed successfully, they were called SPS-LS2.5, SPS-LS5, SPS-LS7.5, SPS-LS10, and SPS-LS12.5, respectively. The polymer membranes were characterized extensively by analysis of functional groups (FTIR), mechanical properties (Tensile tester), and methanol permeability.

The FTIR spectra of the sulfonated polystyrene (SPS), the lignosulfonate (LS), and the SPS-LS are presented in Figure 3. The spectra of the SPS show absorption peaks at $1165-1180$ and $1032 \mathrm{~cm}^{-1}$, indicating symmetric stretching vibrations of the aromatic $-\mathrm{SO}_{3} \mathrm{H}$.The increased sharpness of the absorption peak at $831 \mathrm{~cm}^{-1}$ shows the attachment of sulfonic acid groups at para position $[18,19]$. The peak identified at $1363 \mathrm{~cm}^{-1}$ is due to the asymmetric stretching of the $\mathrm{S}=\mathrm{O}$ bond. The symmetric vibration of this bond produces the characteristic peak split of absorbance at $1150-1185 \mathrm{~cm}^{-1}[16,18]$. Additionally, the absorption peak at $3450 \mathrm{~cm}^{-1}$ is attributed to vibration of $-\mathrm{OH}$ from the $-\mathrm{SO}_{3} \mathrm{H}$ group.

The FTIR spectra of the SPS-LS membranes are shown in Figure 3. Compared to the spectra of the SPS and the lignosulfonate (LS), the absorption peaks of the SPS-LS membrane are a combination of the absorption peaks of the SPS and the LS. The presence of absorption peaks at $3500 \mathrm{~cm}^{-1}, 3100-2840 \mathrm{~cm}^{-1}$, 
and $1700-1600 \mathrm{~cm}^{-1}$ indicates $\mathrm{O}-\mathrm{H}$ stretching vibration, $\mathrm{C}=\mathrm{C}$ group of a nonsymmetric alkene in SPS and LS, and $\mathrm{C}=\mathrm{O}$ stretching in LS molecular, respectively. They refer to the phenolic hydroxyl groups and carbonyl groups of the LS [20]. These FTIR absorption peaks reveal that the LS was incorporated into the SPS.

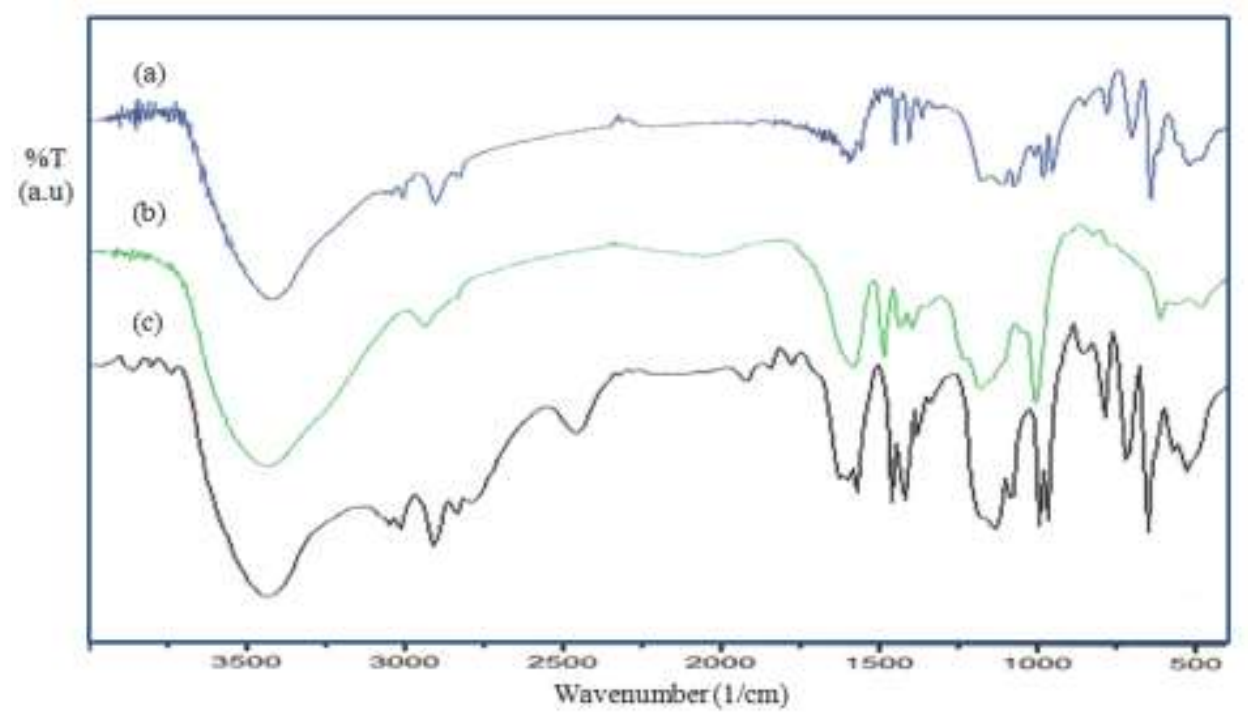

Figure 3 FTIR spectra of (a) SPS, (b) LS and (c) SPS-LS7.5.

One of the most important evaluations for a proton exchange membrane (PEM) is the analysis of its mechanical properties. In this work, the Young modulus of the SPS and the SPS-LS membranes were performed on an Instron tensile tester with a strain speed of $50 \mathrm{~mm} / \mathrm{min}$. Tensile strength and elongation at an elastic state of all membranes were evaluated at room temperature in fully hydrated states, of which the results are shown in Table 1. It can be seen that all membranes exhibited high Young modulus ranging from 414.41 to $610.25 \mathrm{MPa}$.

Table 1 Mechanical properties of the SPS-LS membranes.

\begin{tabular}{lccc}
\hline \multicolumn{1}{c}{ Membrane } & Stress (MPa) & Strain $(\%)$ & Young Modulus (MPa) \\
\hline SPS & 11.84 & 2.31 & 512.09 \\
SPS-LS2.5 & 14.43 & 2.54 & 567.87 \\
SPS-LS5 & 14.62 & 2.42 & 604.80 \\
SPS-LS7.5 & 15.84 & 2.61 & 610.25 \\
SPS-LS10 & 11.41 & 2.63 & 434.75 \\
SPS-LS12.5 & 11.74 & 2.83 & 414.41 \\
\hline
\end{tabular}

Addition of LS into the SPS membrane can increase the mechanical strength. This is caused by the presence of high cross-linking of LS [20], which can 
improve the membrane's mechanical strength. However, at a high weight ratio of LS, the Young modulus for the membranes decreases. The excessive LS can form a layer on the surface and disturb the membrane surface, especially through the formation of larger pores. This result was reported in a previous paper [21]. On the other hand, the elongation of the membrane increases with increasing LS content in the membranes.

Besides proton conductivity, the methanol permeability is one of the most important parameters for electrolyte membranes, particularly for the development of DMFC technology. The methanol permeability or methanol cross-over is a phenomenon of absorption of methanol as a fuel from the anode chamber through the membrane into the cathode chamber. Methanol cross-over in a DMFC can occur through diffusion and electro osmotic drag (EOD).

According to David P. Wilkinson, et al., 2010 [22], methanol cross-over is strongly influenced by the structure, morphology, thickness, acid group contents, temperature and concentration of the methanol used. Methanol permeability is reduced by using a thicker membrane material or using an equivalent weight of polymer membranes with a high. The ideal electrolyte membrane for a DMFC has no methanol cross-over, but it can transport water to the cathode to prevent drying of the cathode catalyst layer. Because of the similar properties of water and methanol it is difficult to separate methanol transport from water transport in the DMFC, which could be done to minimize methanol permeability. Analysis of methanol cross-over of the SPS-LS has been performed by a diffusion cell. Methanol cross-over analysis has been done on the SPS-LS-LS2.5, SPS-LS7.5, and SPS-LS12.5. The results of the calculation ranged from $2.06 \times 10^{-6}$ to $2.15 \times 10^{-6} \mathrm{~cm} / \mathrm{s}$. The methanol permeability profile is shown in Figure 4. The methanol cross-over of Nafion ${ }^{\circledR} 117$ with the same treatment and measurement conditions is $2.08 \times 10^{-6} \mathrm{~cm} / \mathrm{s}$.

Figure 4 shows that the methanol permeability increased as the LS ratio in the membranes increased. An increase of LS content in the SPS-LS membrane can increase the sulfonate $\left(-\mathrm{SO}_{3} \mathrm{H}\right)$ and carboxylic $(-\mathrm{COOH})$ groups in the membranes, so the hydrophilic property of the membranes also increases, as shown in the FTIR spectra, and this property can increase the proton conductivity and water uptake of the membranes [21], which supports methanol to pass through the membrane. However, the methanol cross-over value of SPSLS7.5 is similar to that of a Nafion ${ }^{\circledR} 117$ membrane under the same measurement conditions. Based on the physicochemical properties of the membranes, especially the mechanical properties, methanol permeability and also proton conductivity [21], being close to that of a Nafion ${ }^{\circledR} 117$ membrane, this membrane is potentially useful for DMFC application. 


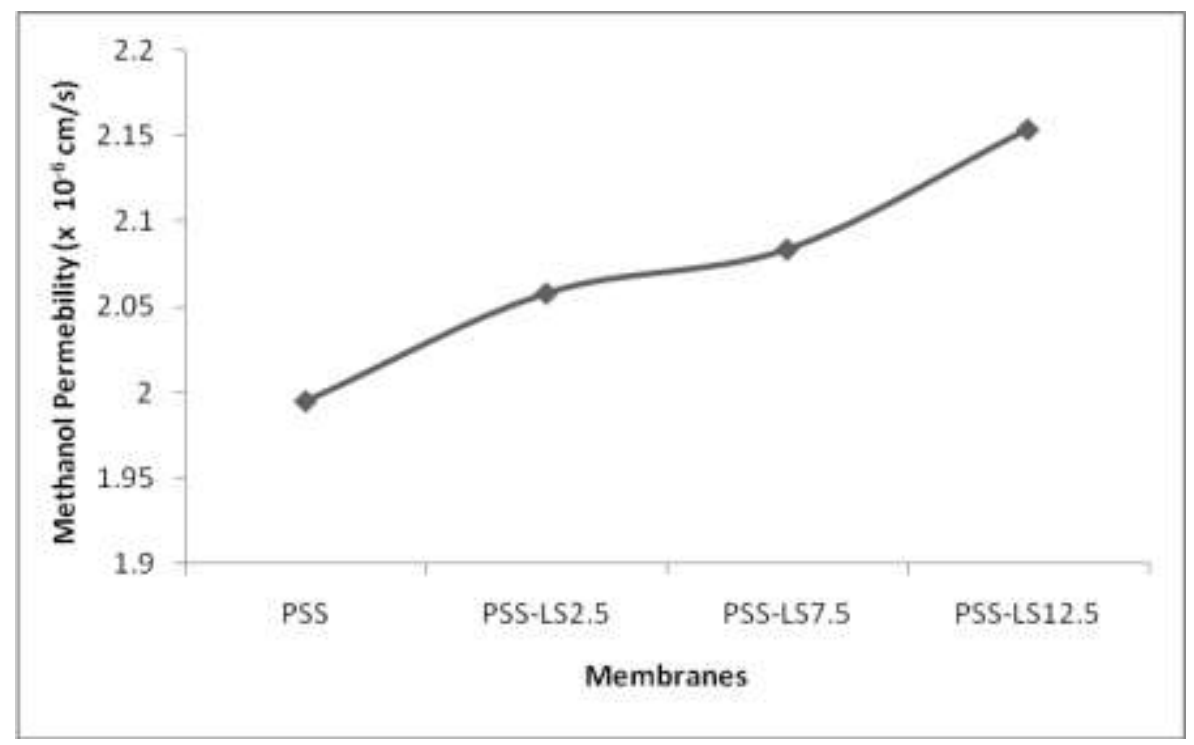

Figure 4 Methanol permeability of SPS-LS membranes.

\section{Conclusion}

A new type of electrolyte membrane material for DMFCs has been prepared by blending SPS with LS through casting a polymer solution. The SPS-LS membranes show maximum tensile strength and Young modulus at an LS ratio of $7.5 \%$. However, the presence of LS in the membranes can increase the methanol cross-over of the membranes. The properties of the membrane, especially the mechanical properties and methanol permeability, are close to those of the Nafion ${ }^{\circledR} 117$ membrane, so this membrane is potentially useful for DMFC application.

\section{Acknowledgements}

The financial support for this research was provided by the General Directorate of Higher Education, Department of National Education, and the Ministry of Research and Technology, Republic Indonesia through competitive research grants. The authors gratefully acknowledge the support of the Institute for Research, LPPM, Institut Teknologi Bandung and Tadulako University.

\section{References}

[1] Zaidi, S.M.J. \& Matsuura, T., Polymer Membranes for Fuel Cells, New York, Springer, 2009. 
[2] Vasquez, L.O., Fuel Cell Research Trends, New York, Nova Science Publishers, Inc., 2007.

[3] Zhao, T.S., Kreuer, K.D.\& Nguyen, T.V., New York, Advances in Fuel Cell, Elsevier,2007.

[4] Sammes, N., Fuel Cell Technology, London, Springer Verlag, 2006.

[5] Larminie, J. \& Dioks, A., Fuel Cell Systems Explained, New York, John Wiley \& Sons. Ltd, 2003.

[6] Zhao, T.S., Micro Fuel Cells Principles and Applications, London, Academic Press, 2009.

[7] Chen, S.L., Bocarsly, A.B.\& Benziger, J, 2005, Nafion-Layered Sulfonated Polysulfone Fuel Cell Membranes, J. Power Sources, 152, $27-$ 33.

[8] Dai, C.A., Liu, C.P., Lee, Y.H., Chang,C.J., Chao, C.Y.\&Cheng, Y.Y., Fabrication of Novel Proton Exchange Membranes for DMFC via UV Curing, J. Power Sources, 177, pp. 262-272, 2008.

[9] Lee, C.H., Park, C.H.\& Lee, Y.M., Sulfonated Polyimide Membranes Grafted with Sulfoalkylated Side Chains for Proton Exchange Membrane Fuel Cell (PEMFC) Applications, J. Memb. Sci., 313, pp. 199-206, 2008.

[10] Chen, X., Yin, Y., Chen, P., Kita, H.\& Okamoto, K.I., Synthesis and Properties of Novel Sulfonated Polyimides Derived from Naphthalenic Dianhydridefor Fuel Cell Application, J. Memb. Sci., 313, pp. 106-119, 2008.

[11] Heo, K.B., Lee, H.J., Kim, H.J., Kim, B.S., Lee, S.Y., Cho, E., Oh, I.H., Hong, S.A.\& Lim, T.H., Synthesis and Characterization of Cross-Linked Poly(Ether Sulfone) for A Fuel Cell Membrane, J. Power Sources, 172,pp. 215-219, 2007.

[12] Tiitu, M., Torkkeli, M., Serimaa, R., Makela, T. \& I kkala, O.T., SelfAssembly and Flow Alignment of Protonically Conducting Complexes of Polystyrene-Block-Poly(4-Vinylpyridine) Diblock Copolymer with Phosphoric Acid, Solid State Ionic, 176, pp. 1291-1299, 2005.

[13] Shin, J.P., Chang, B.J., Kim, J.H., Lee, S.B.\&Suh, D.H, Sulfonated Polystyrene/PTFE Composite Membranes, J. Memb. Sci., 251, pp. 247254, 2005.

[14] Zhang, X., Benavente, J. \& Valls, R.G., Porous Lignosulfonate Membranes for Direct Methanol Fuel Cells, J. Memb. Sci., 276, pp. 301307, 2006.

[15] Carretta, N., Tricoli, V. \& Picchioni, F., Ionomeric Membranes Based on Partially Sulfonated Poly(Styrene): Synthesis, Proton Conduction and Methanol Permeation, J. Memb. Sci., 166,pp. 189-197, 2000.

[16] Smitha, B., Sridhar, S. \& Khan, A.A., Synthesis and Characterization of Proton Conduction Polymer Membranes for Fuel Cell, J. Memb. Sci., 225, pp. 63-76, 2003. 
[17] Zhu, X., Liang,Y., Pan, H., Jian, X. \&Zhang, Y.,Synthesis and Properties of Novel H-Bonded Composite Membranes from Sulfonated Poly(Phthalazinone Ether)S for PEMFC, J. Memb. Sci., 312, pp. 59-65, 2008.

[18] Guan, R., Zou, H., Lu, D., Gong, C. \&Liu, Y., Polyethersulfone Sulfonated by Chlorosulfonic Acid Andits Membrane Characteristics, European Polymer Journal, 41, pp. 1554-1560, 2005.

[19] Martins, C.R., Ruggeri,G. \&Paoli, M.A.D, Synthesis in Pilot Plant Scale and Physical Properties of Sulfonated Polystyrene,J. Braz. Chem. Soc., 14, pp. 797-802, 2003.

[20] Zhang, X., Benavente, J. \& Valls, R.G., Lignin-Based Membranes for Electrolyte Transference, J. Powes Sources, 145, pp. 292-297, 2005.

[21] Gonggo, S.T., Arcana, I.M., Radiman, C.L. \& Bundjali, B, Synthesis and Characterization of Polyblends from Sulfonated PolystyreneLignosulfonate as Ionomer Membranes, International Journal of Materials Science (IJoMS), 6, pp. 1-14, 2011.

[22] Wilkinson, Zhang, D.P.J., Hui, R., Fergus, J. \& Li, X., Proton Exchange Membrane Fuel Cell Material Properties and Performance, New York, CRC Press, 2010. 